\title{
Injury Patterns among Forestry Workers in Croatia
}

\author{
Matija Landekić ${ }^{1}$, Ivan Martinić ${ }^{1}$, David Mijoč ${ }^{2}$, Matija Bakarić ${ }^{1}$ and Mario Šporčić ${ }^{1, *}$ \\ 1 Department of Forest Engineering, Faculty of Forestry and Wood Technology, University of Zagreb, \\ Svetošimunska Cesta 23, 10000 Zagreb, Croatia; mlandekic@sumfak.unizg.hr (M.L.); \\ imartinic@sumfak.unizg.hr (I.M.); mbakaric@sumfak.unizg.hr (M.B.) \\ 2 Hercegbosanske Šume Ltd. Kupres, Splitska bb, 80320 Kupres, Bosnia and Herzegovina; dmijoc@gmail.com \\ * Correspondence: msporcic@sumfak.unizg.hr
}

Citation: Landekić, M.; Martinić, I.; Mijoč, D.; Bakarić, M.; Šporčić, M.

Injury Patterns among Forestry Workers in Croatia. Forests 2021, 12, 1356. https://doi.org/10.3390/ f12101356

\section{Academic Editors:}

Giuseppe Zimbalatti, Bruno Bernardi and Andrea R. Proto

Received: 16 September 2021

Accepted: 2 October 2021

Published: 6 October 2021

Publisher's Note: MDPI stays neutral with regard to jurisdictional claims in published maps and institutional affiliations.

Copyright: (c) 2021 by the authors. Licensee MDPI, Basel, Switzerland. This article is an open access article distributed under the terms and conditions of the Creative Commons Attribution (CC BY) license (https:/ / creativecommons.org/licenses/by/ $4.0 /)$.

\begin{abstract}
Timber harvesting, especially motor-manual felling, in Croatia, as in many other countries, is one of the most hazardous economic activities. Consequently, the aim of this paper is to analyse and compare the latest trends and risk factors related to the incidence of work-induced injuries in structural organization units of national forest enterprise. A combined approach of literature review and assembled secondary data was applied to gather data on workplace accidents over the years 2014-2020. Work-induced injuries data were drawn from the records of the national enterprise Croatian Forests Ltd. which manages state forests (76\% of total forest area). A total of 1626 workinduced injuries were processed and entered into the database. Data analysis was conducted using statistical and descriptive methods. Research results have proven a significant difference in the injury rate over the years 2014-2020 in the Croatian forest enterprise. During the analysed period the highest number of workplace accidents (51.35\% of all recorded workplace accidents) occurred during the forest harvesting phase, i.e., during motor-manual felling. Trends in the incidence of work-induced injuries in the observed period do not show any significant improvement. The key findings have pointed out that forest administrations which practice even-aged forest management have $25 \%$ or more injuries than forest administrations which practice selective forest management. Related to the average rate of change by forest administration, the largest annual increase or decrease of the selected safety indicators is recorded for smallest forest administrations. Related to total number of injuries, the smallest forest administrations have the least injuries and show statistically significant difference compared to large forest administrations. When comparing the number of injuries per 1000 employees, medium sized forest administrations have the highest value of indicator and show statistical significance. Discussion and conclusion of the paper emphasizes the need for systematic research in the field of ergonomy, safety and health of forest workers in Croatian forestry sector. Additionally, the development and inclusion of proactive safety culture is recognized as a mechanism that can further reduce work injuries and improve occupational safety which should have a significant role in the process of certification of forest management according to the FSC standard.
\end{abstract}

Keywords: forestry; safety and health; forest workers; occupational injuries; Croatia

\section{Introduction}

The forestry sector is in many national economies one of the industries with the highest injury risk [1,2]. Despite the introduction of modern technologies, forest production is considered to be one of the most dangerous work-related activities with high mortality rate and numerous accidents [2-4]. Because of the natural environment, high loads and frequent use of hand tools and machines, workers are exposed to significant physical, psychological and environmental influences that result in various diseases, especially those related to the muscular, bone, nerve, vascular and auditory systems [5-7].

Forestry work is generally characterized as demeaning, dirty and dangerous (3D) work requiring unnatural and uncomfortable working postures and exposures to noise and vibration. Because of the above, a significant lack of interest of young generations is 
observed for the so-called 3D «black collar» jobs, such as the job positions of a tree feller, choker-man, skidder driver, etc. Tree felling is the deadliest occupation in forestry; in developing countries, chainsaws may be involved in nearly half of all forestry accidents [8]. Significant improvements in chainsaw safety have been made in recent years. However, given the prevalence of chainsaws in the forest sector and their potential to cause injuries and fatalities, special attention should be paid to investigating, reporting and analysing chainsaw accidents [2].

Comparative statistics from different countries have shown that the forestry industry has a higher frequency rate of work-related accidents than other sectors of industry $[9,10]$. Reliable data that do exist suggest that forestry-related work is among the most hazardous of all non-military activities [11]. A more detailed analysis of accidents in the forestry sector has shown that the work on the wood utilization is far more dangerous than other operations in forestry [12]. Work-related health issues in forest enterprises are recorded in many countries, both developing and developed, such as Slovenia, Slovakia, Croatia, etc. [1,13-15]. It has been reported that timber harvesting is responsible for $65-80 \%$ of all the accidents in the forestry sector [16]. In Indonesia, for example, timber harvestingrelated accidents contributed $9 \%$ to the total national fatal accidents record between 1995 and 1999, accounting for 232 deaths [17]. Analyzing occupational injuries in Slovenian state forests in the period 1990-2005, Potočnik and associates [13] found that $68 \%$ of injuries occurred during the felling and processing phase, $24 \%$ during the skidding or forvarding phase and only $6 \%$ during silvicultaral work. In Slovakia, where motor-manual forestry technology also predominates, Suchomel and associates [14] recorded the largest number of injuries in the technological process of forest exploitation (62\%), citing a lack of knowledge about proper working procedures (about 66\%) as the dominant cause of injuries. A recent analysis from 2019, according to Gejdoš and associates [1], for Slovakia shows that the highest number of workplace accidents (31.8\% of all recorded workplace accidents) occurred during forest harvesting. Analysis of safety at work in forestry of the Bosnia and Herzegovina Federation during the period 2006-2015 [18] resulted with the highest number of accidents in the harvesting process $(66.3 \%)$, while the most hazardous occupation is chainsaw operator $(57.7 \%)$.

Although technological advances and workplace safety management systems have contributed greatly to the creation of a more secure world, the introduction and improvement of safety culture in the workplace is the key to further improvements [19]. A sound safety culture recognizes that accidents will likely occur. The challenge is to reduce or avoid the consequences of such accidents [11]. A true safety culture ensures every employee has the best chance of going home to his or her family at the end of a workday injury-free [20]. Key factors such as effective communication and training, building relationships and trust and an accessible hazard reporting system are cornerstones of companies with a good safety culture.

Croatian forestry workers are not an exception to the occupational safety and health problems facing forestry workers worldwide. Occupational accidents and related diseases have been a serious challenge for Croatian forestry sector over the past twenty years. In accordance with the stated, the aim of the paper is to analyse and compare the latest trends and risk factors related to incidence of work-induced injuries in Croatian forest enterprise.

\section{Materials and Methods}

A case study research method was applied to investigate injury patterns in Croatian forestry; more precisely in the national company Croatian Forests Ltd. (CF Ltd., Zagreb, Croatia) for the period from 2014 to 2020. The company Croatian Forests Ltd. manages state forests which constitute $76 \%$ of the total forest area in Croatia, and represents the most significant single stakeholder in Croatian forestry. In 2009, Yin [21] gave a comprehensive coverage of the design and use of the case study method as a valid research tool. Multiple in-depth case studies of organisational units provided the opportunity to compare data from the CF Ltd. Headquarter and their 17 Forest Administrations (FA), generate more 
compelling results and offer greater potential for explanation of the latest injury patterns of forestry workers in Croatia. With the aim of better visualization and comparability of occupational safety indicators, seventeen Forest administrations are classified, according to the criteria of the number of employees and the realization of the annual felling volume, into large (L), medium (M) or small (S) sized FA (shown in Table 1 and Table 3).

Table 1. Key descriptive values for classification of Forest administrations.

\begin{tabular}{ccccccccc}
\hline \multirow{2}{*}{$\begin{array}{c}\text { Forest } \\
\text { Administratio Class }\end{array}$} & \multicolumn{3}{c}{ Number of Employees } & \multicolumn{4}{c}{ Realization of the Annual Felling Volume, $\mathbf{m}^{\mathbf{3}}$} \\
\cline { 2 - 9 } & Means & Std. Dev. & Min. & Max. & Means & Std. Dev. & Min. & Max. \\
\hline Small (S) & 281.11 & 61.62 & 148 & 361 & $75,823.30$ & $50,296.67$ & 368 & 136,674 \\
Medium (M) & 489.71 & 65.15 & 352 & 591 & $189,612.60$ & $32,921.37$ & 147,327 & 257,266 \\
Large (L) & 684.26 & 123.71 & 419 & 907 & $231,963.80$ & $88,387.22$ & 125,490 & 402,818 \\
\hline
\end{tabular}

The collection of secondary information [22], related to the calculation of occupational safety indicators, was carried out via the Work Protection Service which is organized in the company CF Ltd. with the view of implementing work safety. Among others, this Service is responsible for statistics related to worker safety and health. For the purposes of this paper, and with the aim of safety indicators data analysis, reports of the Work Protection Service in CF Ltd. were collected for the period from 2014 to 2020.

Standard indicators of safety at work in CF Ltd. used in the analysis are the total number of injuries, the number of injuries for felled and processed wood, the number of injuries per 10,000 $\mathrm{m}^{3}$ of felled and processed wood and the number of injuries per 1000 employees. The number of injuries in each organizational unit is one of the key safety indicators. It is most often expressed in absolute terms as the annual number of injuries, and as a relative indicator of the number of injuries in the total number of workers (all production and non-production workers) and in the number of production workers, because including a large share of workers who are not directly involved in production can create a misconception.

Methods of analysis and synthesis, comparison and compilation were used in the processing of data and drafting of the paper. Analysis and synthesis method were used in the paper drafting, where various sources were ultimately summed up in a single text. Method of comparison was used in the practical part of the work for a display of the injury statistics of forestry workers in the company CF Ltd.

\subsection{Research Case}

Forests and forest land in the Republic of Croatia (RC) cover 2.759 million hectares or approximately $47 \%$ of the total area of RC. Of the total area of forests and forest land, $2,097,318.16$ hectares $(76 \%)$ are owned by the $R C$, and $661,720.89$ hectares $(24 \%)$ are owned by private forest owners. Commercial state forests in Croatia are mostly managed by the company Croatian Forests Ltd. (CF LTD) - approximately $76 \%$ of the total forest area, or 2,097,318.16 ha [23]. The company CF Ltd. has a three-tier organizational structure: the first level is the headquarters in Zagreb, 17 forest administrations (FA) are regional units of the second level, and 169 forest offices (FO) and 21 working units (WU) are the local units in the third level. Forest office is the core organizational unit which carries out the basic tasks of forestry activities: restoration and silviculture, harvesting, production, skidding/forwarding and transporting of forest assortments, etc. [24]. Business results, but also injury statistics, of individual structural/organizational units in Croatian Forests Ltd. (forest office, forest administrations) are very different, among other things because of position rent which binds many organizational and productional advantages or disadvantages. The company CF Ltd. has employed between 7900 and 8400 workers for the last 7 years [24]. The number of licensed contractors in forestry is currently about 360 , and the exact number of total employees is unknown (it changes on a monthly basis). Timber extraction is mechanized, while felling and processing are mostly motor-manual 
and carried out using chainsaws [25]. The first harvester (Timberjack 1070) was introduced in Croatia in 2001 for the purpose of scientific research, and a second one a year later (Timberjack 1270B). However, the state-owned company Croatian Forests Ltd. purchased their first harvester in 2018-before that, there were only few machines owned by private contractors [26]. In the observed seven-year period the number of harvesters increases, and $3 \%-4 \%$ of wood is felled fully mechanized in state forests. There are currently about 40 harvesters in Croatia, of which 4 are owned by CF Ltd. and the remaining are owned by private forestry contractors.

\subsection{Statistical Analysis of Data}

The base for input of collected data, systematization and assessment of the entry and the primary processing of the collected data was made in the software package Microsoft Excel $^{\circledR}$. Further data analysis was performed using statistical software: Statistica $13^{\circledR}$ (Dell Software, Round Rock, TX, USA) and SAS $9.4^{\circledR}$ (Cary, NC, USA).

In data processing, a descriptive statistical analysis was applied, which includes a set of methods that are used for calculating, displaying and describing the main characteristics of statistical series. In this paper it was used for grouping and sorting statistical data, and for the numerical and graphical display of the research results regarding standard indicators of safety at work in company CF Ltd.

The average rate of change is calculated through relative measures of change of some phenomenon with respect to the previous period (i.e., chain index) and is expressed as a percentage (Equation (1)). In the paper it was used to show by what percentage on average each year the standard occupational safety indicators changed in the period from 2014 to 2020.

$$
\bar{S}=\left(\sqrt[n-1]{\frac{y_{n}}{y_{1}}}-1\right) \times 100
$$

A chi-squared test, also written as $\chi^{2}$ test, was used to determine whether there is a statistically significant difference between the expected frequencies and the observed frequencies for the total number of injuries at work by organizational units of the company within the sampled period.

Correspondence analysis as a data science tool for summarizing tables was used for better visualization and interpretation of the total number of injuries and the number of injuries for felled and processed wood where on the correspondence analysis map labels with similar residuals close together are plotted. In addition, given a row value and a column value in interpretation, the longer their distance to the origin, the stronger is their association with other points on the map, and the smaller the angle between the two points, the higher is the correlation between the two.

Analysis of variance was used to test the differences between large (L), medium (M) and small (S) FA group for the total number of injuries and the number of injuries per 1000 employees.

\section{Results}

The seven-year trend of selected safety indicators in the company Croatian Forests Ltd. is shown in Table 2. The first indicator, the number of injuries per year, in the observed period ranges from 210 to 255 , and the largest number of injuries was recorded in 2018. The number of injuries during felling and processing of wood, within the seven-year period, participates with $57.28 \%$ to $46.19 \%$ of the total number of injuries in the company that manages the state forests of the Republic of Croatia (values in the brackets). The indicator related to the number of injuries per 1000 employees ranges from 26.98 in 2014 to 34.01 in 2016. The third indicator related to the number of injuries regarding felled and processed wood per 10,000 $\mathrm{m}^{3}$ records approximately half the value of the total number of injuries per 10,000 $\mathrm{m}^{3}$ of harvested wood (Table 2). 
Table 2. Summary of selected safety indicators in the company CF Ltd.

\begin{tabular}{|c|c|c|c|c|}
\hline Year & Number of Injuries & Fatal Injuries & $\begin{array}{c}\text { Injuries Per } 1000 \\
\text { Employees }\end{array}$ & $\begin{array}{c}\text { Injuries Per } \\
10,000 \mathrm{~m}^{3}\end{array}$ \\
\hline 2014 & $213(122)^{1}$ & 2 & 26.98 & $0.81(0.46)^{1}$ \\
\hline 2015 & $237(126)^{1}$ & 1 & 30.99 & $0.86(0.45)^{1}$ \\
\hline 2016 & $253(129)^{1}$ & 1 & 34.01 & $0.99(0.50)^{1}$ \\
\hline 2017 & $210(97)^{1}$ & 0 & 27.45 & $0.79(0.36)^{1}$ \\
\hline 2018 & $255(122)^{1}$ & 1 & 31.68 & $0.88(0.42)^{1}$ \\
\hline 2019 & $232(115)^{1}$ & 0 & 29.07 & $0.92(0.45)^{1}$ \\
\hline 2020 & $226(124)^{1}$ & 2 & 28.23 & $0.92(0.51)^{1}$ \\
\hline
\end{tabular}

${ }^{1}$ Data related only to recorded injuries for felled and processed wood with CF Ltd. internal (own) capacities.

The number of injuries at work in each organizational unit is one of the key safety indicators. Table 3 shows that forest administrations in group L (Vinkovci, Našice i Bjelovar), where even-aged forest management is practiced, have on average a minimum of 20 injuries per year. On the other hand, FA Delnice and Gospić, where selective forest management is practiced, have on average five injuries less (approximately 15 injuries per year for the observed period). The number of recorded injuries for felled and processed wood in L group on average is minimum 10 per year in all FA except FA Delnice (Table 3). The highest average value for the number of injuries per 1000 employees in the observed period was recorded in the FA Našice (37.80) and Bjelovar (29.80) within the L group, and for the injuries per 10,000 $\mathrm{m}^{3}$ in the FA Gospić and Našice (Table 3). In M group (Table 3) FM Osijek, Zagreb and N. Gradiška have on average a minimum of 20 injuries per year. The highest average value for the number of recorded injuries for felled and processed wood in M group (Table 3) is in FA N. Gradiška (14.00) and Zagreb (10.14). The highest average value for the number of injuries per 1000 employees in the observed period was recorded in the FA Osijek (54.21) and N. Gradiška (44.44), and for the injuries per 10,000 $\mathrm{m}^{3}$ in the FA N. Gradiška and Zagreb (Table 3). FA Požega, Senj and Slatina have on average a minimum of 10 injuries per year in S group (Table 3), and the highest average value for the number of recorded injuries for felled and processed wood is in FA Slatina (7.00) and Požega (6.14). FA Buzet and Split (S group) due to the number of employees and the small share of the most risky operations in forestry achieve the best values for the observed indicator (Table 3). The highest average value for the number of injuries per 1000 employees in the observed period was recorded in the FA Senj (39.18), Požega (37.37) and Slatina (33.51) within the $S$ group, and for the injuries per 10,000 $\mathrm{m}^{3}$ by in the FA Buzet and Senj (Table 3).

Table 3. Descriptive statistics of selected safety indicators for organizational units of the company CF Ltd. by size class.

\begin{tabular}{|c|c|c|c|c|c|c|c|}
\hline Class by Size & FA & Indicator & Mean & Median & Minimum & Maximum & Std. Dev. \\
\hline \multirow{3}{*}{ Large (L) } & Vinkovci $^{a}$ & Injuries total & $19.06(9.91)^{1}$ & $18(10)^{1}$ & $7(3)^{1}$ & $31(17)^{1}$ & $4.40(2.84)^{1}$ \\
\hline & Našice $^{\text {a }}$; & Injuries per $10,000 \mathrm{~m}^{3}$ & $0.88(0.46)^{1}$ & $0.90(0.47)^{1}$ & $0.46(0.11)^{1}$ & $1.42(0.93)^{1}$ & $0.21(0.13)^{1}$ \\
\hline & $\begin{array}{l}\text { Delnice }{ }^{\text {b; }} \text { ' } \\
\text { Gospić }^{b}\end{array}$ & $\begin{array}{c}\text { Injuries per } 1000 \\
\text { employees }\end{array}$ & 28.07 & 26.79 & 11.57 & 47.85 & 6.47 \\
\hline \multirow{3}{*}{ Medium (M) } & Osijek $^{a}$; & Injuries total & $18.29(9.26)^{1}$ & $18(9)^{1}$ & $7(3)^{1}$ & $31(20)^{1}$ & $5.68(3.55)^{1}$ \\
\hline & Koprivnica $^{a}$; & Injuries per $10,000 \mathrm{~m}^{3}$ & $0.98(0.50)^{1}$ & $0.95(0.49)^{1}$ & $0.36(0.16)^{1}$ & $2.19(1.56)^{1}$ & $0.31(0.19)^{1}$ \\
\hline & $\begin{array}{c}\text { Karlovac }{ }^{c} \text {; } \\
\text { N. Gradiška }{ }^{a}\end{array}$ & $\begin{array}{c}\text { Injuries per } 1000 \\
\text { employees }\end{array}$ & 35.86 & 34.22 & 14.86 & 67.47 & 10.19 \\
\hline \multirow[b]{3}{*}{ Small (S) } & Požega ${ }^{a}$ & Injuries total & $7.66(4.06)^{1}$ & $7(4)^{1}$ & $0.00(0.00)^{1}$ & $16(9)^{1}$ & $2.58(1.61)^{1}$ \\
\hline & $\begin{array}{l}\text { Sisak }^{a} \text {; } \\
\text { Ogulin }{ }^{c} \text {. }\end{array}$ & Injuries per $10,000 \mathrm{~m}^{3}$ & $2.17(0.52)^{1}$ & $1.44(0.49)^{1}$ & $0.00(0.00)^{1}$ & $30.82(2.34)^{1}$ & $2.02(0.28)^{1}$ \\
\hline & $\begin{array}{c}\text { Senj }^{c} ; \\
\text { Buzeta }^{\text {a }} \\
\text { Split }^{\text {a }} ; \\
\text { Slatina }^{\text {a }}\end{array}$ & $\begin{array}{c}\text { Injuries per } 1000 \\
\text { employees }\end{array}$ & 25.67 & 23.80 & 0.00 & 55.36 & 9.17 \\
\hline
\end{tabular}

${ }^{1}$ Data related only to recorded injuries in felling and wood processing phase of harvesting (only CF Ltd. internal capacities). Practiced forest management system: ${ }^{a}$ even-aged; ${ }^{b}$ selective; ${ }^{c}$ combination of both. 
The total number of injuries for FAs in group L, in the observed period 2014-2020, decreases on average from 1.23 to $7.64 \%$, except for FA Bjelovar where it increases by $1.34 \%$ annually (Table 4 ). The largest annual increase in the number of injuries for felled and processed wood (L group) is recorded in FA Bjelovar (4.57\%), and the largest annual decrease in FA Našice and Gospić (6.53\%). The highest annual value for the average rate of change (or increase) related to injuries per 1000 employees (L group) is recorded in FA Bjelovar, and the decrease in FA Vinkovci (Table 4). For the group $M$ the total number of injuries increases on average from $1.34 \%$ to $12.25 \%$, except for FA Karlovac where it decrease by $14.56 \%$ annually (Table 4 ). The largest annual increase in the number of injuries for felled and processed wood (M group) is recorded in FA N. Gradiška (12.25\%), and largest annual decrease in FA Osijek and Karlovac (14.16\%). The highest annual value for the average rate of change (or increase) related to injuries per 1000 employees (M group) is recorded in FA N. Gradiška and Osijek, and the decrease in FA Karlovac (Table 4). In the group $S$ the total number of injuries increases on average annually from $4.28 \%$ to $25.99 \%$, except for FA Senj where it decreases by $15.08 \%$ annually (Table 4 ). The largest annual increase in the number of injuries for felled and processed wood ( $\mathrm{S}$ group) is recorded in FA Sisak (17.76\%) and Ogulin (14.47\%), and largest annual decrease in FA Senj (29.29\%) and Slatina (13.40\%). The highest annual increase related to injuries per 1000 employees (S group) is recorded in FA Buzet and Slatina, and the decrease in FA Senj (Table 4).

Table 4. The average rate of change for selected safety indicators by forest administration.

\begin{tabular}{cccccc}
\hline \multirow{2}{*}{$\begin{array}{c}\text { Organisation } \\
\text { Unit }\end{array}$} & $\begin{array}{c}\text { Class by } \\
\text { Size }\end{array}$ & Total & $\begin{array}{c}\text { Related to Felling and } \\
\text { Wood Processing }\end{array}$ & $\begin{array}{c}\text { Per 10,000 } \\
\text { m }^{\mathbf{3}}\end{array}$ & $\begin{array}{c}\text { Per 1000 } \\
\text { Employees }\end{array}$ \\
\cline { 3 - 6 } & & -6.13 & -2.75 & -6.04 & -5.48 \\
FA Vinkovci & Large (L) & -14.16 & 9.59 & 6.23 \\
FA Osijek & Medium (M) & 8.67 & -6.53 & 1.61 & -0.89 \\
FA Našice & Large (L) & -7.64 & -2.54 & -1.94 & -2.99 \\
FA Požega & Small (S) & -1.58 & 4.57 & 2.01 & 2.65 \\
FA Bjelovar & Large (L) & 1.34 & 2.60 & 1.63 & 1.44 \\
FA Koprivnica & Medium (M) & 1.34 & 1.98 & 3.85 & 0.63 \\
FA Zagreb & Medium (M) & 1.98 & 17.76 & 23.19 & 16.52 \\
FA Sisak & Small (S) & 18.36 & -14.16 & -16.02 & -13.10 \\
FA Karlovac & Medium (M) & -14.56 & 14.47 & 8.15 & 5.98 \\
FA Ogulin & Small (S) & 4.28 & 0.00 & -2.72 & -4.06 \\
FA Delnice & Large (L) & -5.77 & -29.29 & -8.52 & -12.23 \\
FA Senj & Small (S) & -15.08 & -6.53 & 2.50 & -2.37 \\
FA Gospić & Large (L) & -1.23 & 0.00 & 29.89 & 25.35 \\
FA Buzet & Small (S) & 25.99 & 0.00 & -38.26 & -2.54 \\
FA Split & Small (S) & 0.00 & 12.25 & 18.73 & 12.21 \\
FA N. Gradiška & Medium (M) & 12.25 & -13.40 & 24.34 & 17.17 \\
FA Slatina ${ }^{2}$ & Small (S) & 18.32 &
\end{tabular}

1 data related only to recorded injuries in felling and wood processing phase of harvesting (only CF Ltd. internal capacities); ${ }^{2}$ data for Forest Administration Slatina is calculated only for two-year period because it was established at the end of 2018.

Using the chi-square test, it was proven that there is a statistically significant difference $\left(\chi^{2}(102, N=126)=188.17 ; p=0.05\right)$ in the values of the total number of recognized injuries at work by organizational units of the company within the sampled period from 2014 to 2020. The observed frequencies of the total number of injuries differ statistically significantly from the expected frequencies at a significance level of 0.05. Observed individual chisquare values by the observed organizational units of the company show that the largest individual contribution was determined in the FA Slatina, which began operating as an independent unit from 2019. Within 2014, FA Našice and Karlovac recorded the largest individual contribution to the established difference, and in 2015 FA Osijek and Delnice. FA Koprivnica in 2018 recorded the largest individual contribution, while in 2020 a significant contribution to the established difference was recorded in FA Osijek, Delnice and Senj. By 
subsequent analysis of the number of injuries that occurred during felling and processing of wood, chi-square test also proved that there is a statistically significant difference $\left(\chi^{2}(90, N=112)=130.44 ; p=0.05\right)$ per organizational units of the company within the sampled period from 2014 to 2020. The largest contribution to the determined difference was recorded at FA Slatina in 2019 and 2020, and at FA Osijek, Našice, Požega, Koprivnica and Zagreb in 2018. In addition to the above, in 2020 a significant individual contribution was recorded at the FA Sisak, Ogulin and Senj, and in 2014 at the FA Našice and Karlovac.

Correspondence analysis map was used for better visualization and interpretation of the total number of injuries and the number of injuries for felled and processed wood versus the sampled years. Figure 1 shows inertia and chi-square decomposition for the total number of recognized injuries at work. The first (horizontal) dimension explains $52.76 \%$ of the variance in the data, whereas the second (vertical) dimension explains 15.51\% (Figure 1). For the values regarding the number of injuries for felled and processed wood, inertia and chi-square decomposition is shown in Figure 2. The first (horizontal) dimension explains $43.26 \%$ of the variance in the data whereas the second (vertical) dimension explains $27.77 \%$ (Figure 2). It can be seen on that on the map, for the total number of recognized injuries at work, points vary more on the horizontal than on the vertical axis (Figure 3)

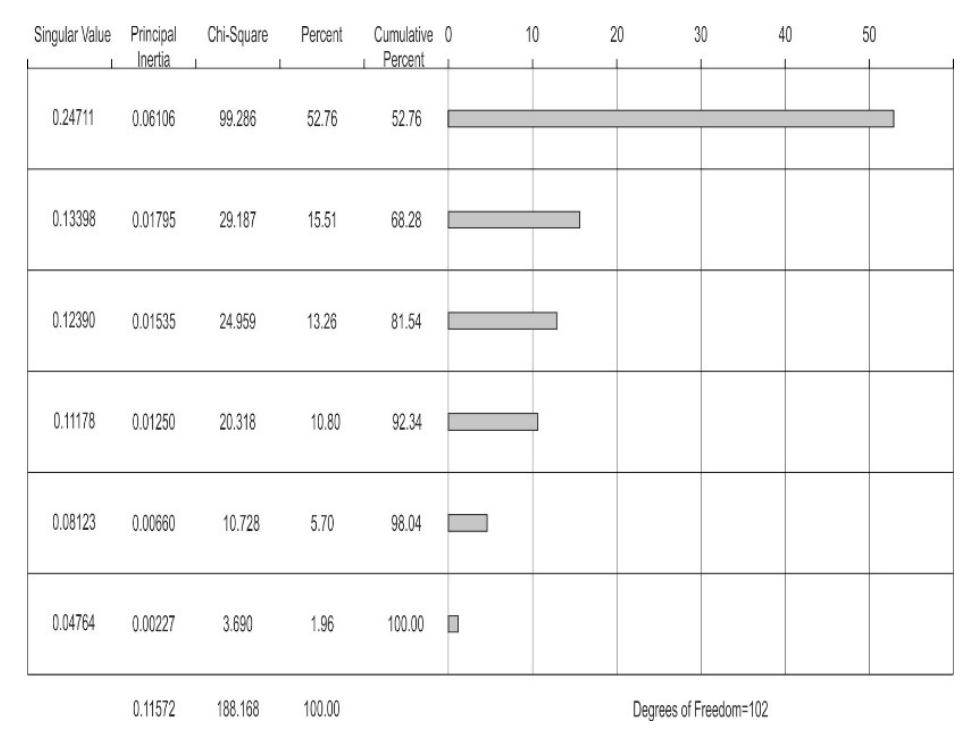

Figure 1. Inertia and chi-square decomposition for injuries in total.

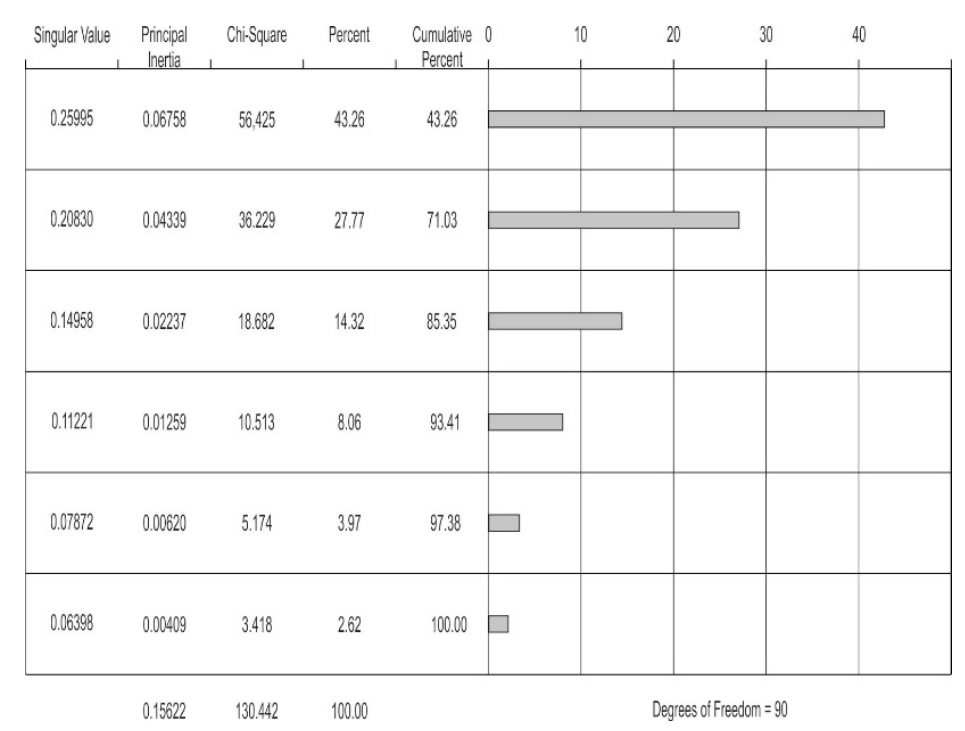

Figure 2. Inertia and chi-square decomposition for injuries related to felled and processed wood. 


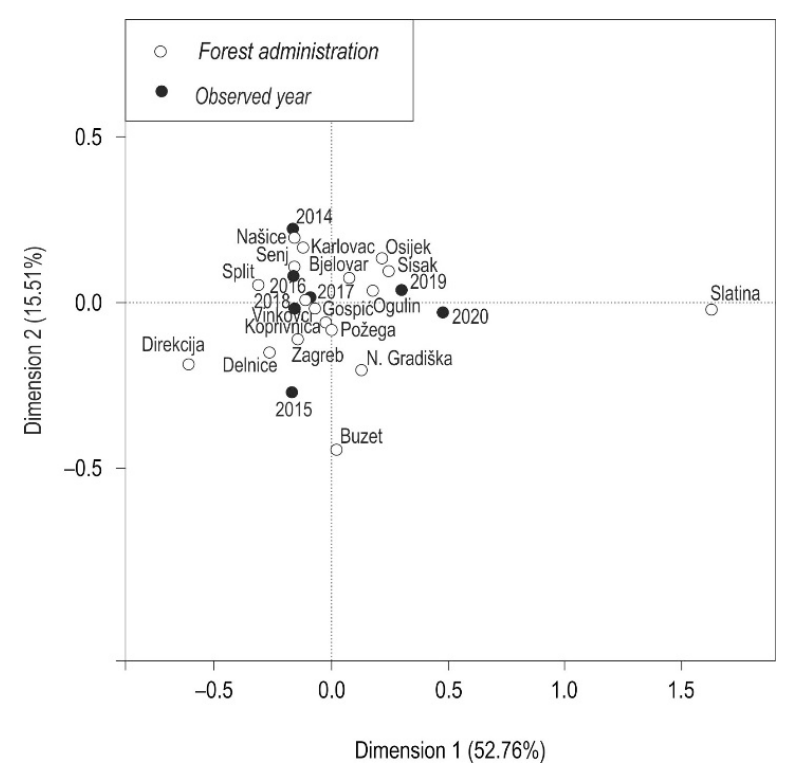

Figure 3. Correspondence analysis map for injuries in total.

The correspondence analysis map in Figure 3 shows that FA Slatina on the right is very differentiated and that it highly correlates with 2020. With 2019, the most pronounced connection is shown by FA Sisak and Osijek when they record a significantly higher number of injuries in total compared to the average value of the sampled period (Figure 3). FA Našice and Karlovac show the most pronounced connection with 2014, while UŠP Zagreb and Buzet correlate with 2015. The analyzed values for the remaining FFS and the sampled years are in the middle of the map (i.e., close to the starting point) which shows that there is very little or no correlation (Figure 3). Labels on the correspondence analysis map for the number of injuries for felled and processed wood versus the sampled years (Figure 4) are less grouped towards the center of the map. On this map, FA Slatina on the left is very differentiated and it highly correlates with 2019 and 2020, and FA Sisak is moderately correlated with 2019 and 2020. FA Koprivnica, Zagreb and Buzet highly correlate with the 2018 because they recorded extremely higher number of injuries for felled and processed wood compared to the average value of the sampled period (Figure 4). On the map, moderate correlation with 2014 also can be seen for the FA Osijek and Našice (Figure 4).

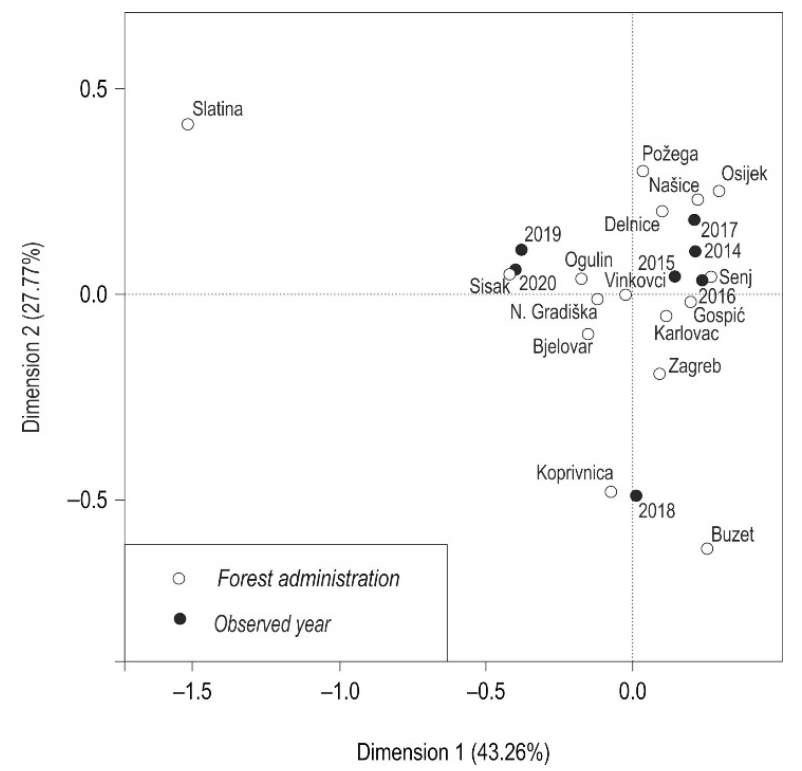

Figure 4. Correspondence analysis map for injuries related to felled and processed wood. 
Analysis of variance was used to test the differences between three defined groups. Since Kolmogorov-Smirnov test proved that annual number of injuries followed normal distribution ( $p$-value $>0.05)$, one-way ANOVA was used to test the difference in the annual number of injuries among three groups (small, medium and large-size forest administrations). The differences were found to be statistically significant with $\mathrm{F}(2,119)=61.55$, $p=0.000$ (Figure 5). Using the Tukey HSD post hoc test, it was determined that the mean annual number of injuries in small-size forest administrations $(\mathrm{M}=6.43 ; \mathrm{SD}=8.44 ; \mathrm{N}=49)$ is significantly different from the medium-size group $(\mathrm{M}=18.29 ; \mathrm{SD}=6.83 ; \mathrm{N}=35)$ and large-size group $(\mathrm{M}=19.06 ; \mathrm{SD}=6.19 ; \mathrm{N}=35)$. Statistically significant difference for annual number of injuries was not determined between medium-size and large-size forest administrations (Figure 5). In second analysis (Figure 6), Kolmogorov-Smirnov test proved also that number of injuries per 1000 employees followed normal distribution ( $p$-value $>0.05$ ). One-way ANOVA was used to test the difference in number of injuries per 1000 employees among three groups (small, medium and large-size forest administrations). The differences were found to be statistically significant with $\mathrm{F}(2,119)=13.01, p=0.000$ (Figure 6). Using the Tukey HSD post hoc test, it was determined that the mean value for number of injuries per 1000 employees in medium-size forest administrations $(\mathrm{M}=38.05 ; \mathrm{SD}=15.31 ; \mathrm{N}=35)$ is significantly different from the small-size group $(\mathrm{M}=22.25 ; \mathrm{SD}=16.02 ; \mathrm{N}=49)$ and large-size group $(\mathrm{M}=28.07 ; \mathrm{SD}=8.56 ; \mathrm{N}=35)$. Statistically significant difference for number of injuries per 1000 employees mean value was not determined between small-size and large-size forest administrations (Figure 6).



Figure 5. Mean value of annual number of injuries between groups.

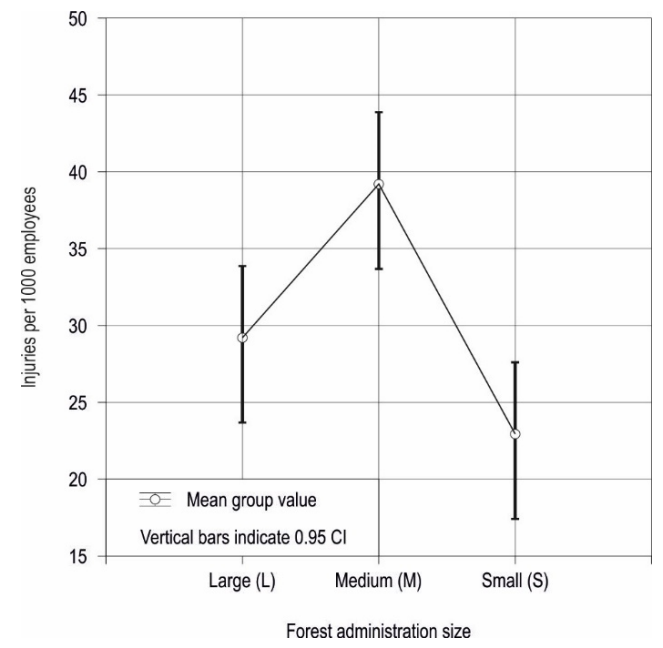

Figure 6. Mean value of injuries per 1000 employees between groups. 


\section{Discussion and Conclusions}

On an annual basis, a heterogeneous trend is visible for the total number of injuries, but also a significant difference in the injury rate over the years 2014-2020 was determined in the analysis for the Croatia forest company. Through the conducted analysis it was not determined whether a significant difference for total number of injuries is in relation to increase or decrease. For Slovakia forestry sector Gejdoš and associates [1] have determined a non-significant decrease in the injury rate over the years 2000-2016.

In the conducted case study the number of injuries per year in the observed period ranges from 210 to 255, and the largest number of injuries was recorded in 2018. The values of the indicator in question achieve a positive result given the average trend of 600 injuries per year recorded in the period from 1991 to 2000 for CF Ltd. [27]. Analyzing the accident rate in both sectors of forestry, Grzywinski and associates [28] observe that it is decreasing slightly in the public sector, but consistently growing in the private sector. The indicator related to the number of injuries per 1000 employees ranges from 26.97 to 34.01 , which is the difference of seven injuries per 1000 employees between the best and the worst annual result. Comparing the second indicator to the state from 2009 when it amounted to 29.4 [29], the safety situation in the company can be described as "regressive" compared to the base year. The above particularly indicates concern when we put the same indicator in relation to the results of research by Grzywinski and associates [30] in Poland where average accident rate in forestry in the years 2003-2017 amounted to 8.19 per 1000 employees or the results of research by Varakina and associates [31] for Arkhangelsk region (Northwest Russia) where a decrease in injury rate was recorded from 43.9 per 1000 employees in the year 1996 to 20.8 per 1000 employees in the year2007. If we put the same indicator (injuries per 1000 employees) in relation to the results of research by Benavides and associates [32] in Spain (44.9 per 1000 employees in the year 2002) or with the situation in neighbouring Federation of Bosnia and Herzegovina where the values range from 31.6 to 60 [18,33], the values for the company CF Ltd. are better but not satisfactory compared to Poland or the Northwest Russia case study. The third indicator (Table 2) within the observed period achieves the best values (0.88), in relation to the situation in Croatian forestry in 2011-1.58 injuries per 10,000 $\mathrm{m}^{3}$ [29], or in relation to the state forestry of Slovenia in 2003-2.2 injuries per $10,000 \mathrm{~m}^{3}$ of wood felled and processed [34].

Comparative analysis of selected safety indicators between organizational units of the company CF Ltd. indicated that the Forest administrations which practice even-aged forest management have $25 \%$ more injuries than Forest administrations which practice selective forest management, particularly pronounced in the L group. The reason for this is that, due to higher quality and more valuable wood mass, a larger amount of annual felling is carried out by the internal capacities of the company. It should be noted that CF Ltd. are not obligated to keep records of the forest contractors' injuries. Related to the indicator of the number of injuries per 1000 employees, FAs with the lowest annual felling and the smallest number of employees (S group) have the same or higher indicator value compared to the FAs in L group, while FAs in group M have the value of the same indicator $60 \%$ higher or more compared to the others. Related to the average rate of change by Forest administration, the largest annual increase or decrease of the selected safety indicators is recorded for FAs which are in group S. In M group, a noticeable annual decrease of analyzed safety indicators is recorded for FA Karlovac and an increase for FA N. Gradiška. The results of the analysis of the variance between the three defined groups in relation to the total number of injuries showed that the FAs in the $S$ group have the least injuries and are statistically significantly different from the other two groups. On the other hand, the analysis of the variance regarding the number of injuries per 1000 employees showed a highest statistically significant number of injuries for FAs in group M. The obtained difference between the two results can be argued through the level of subjectivity or objectivity of the indicator used in the analysis process. The total number of injuries shows the general picture of the situation, while the number of injuries per 1000 employees is a more objective indicator of the level of safety and occurrence trend of injuries at work. 
For the last ten years' trends in the incidence of work-induced injuries, frequency of occupational diseases and premature retirement of forestry workers do not show any significant improvement. In the Croatian forestry sector, work with a chainsaw, the most commonly used tool by forest workers, can be considered one of the most dangerous activities. The results of this study, in addition to the results of Blombäck [8] and Musić and associates [18], showed that in forest operations work with a chainsaw is involved in nearly half or more of all forestry accidents. With the aim of improving the state of health and safety at work in Croatian forest companies, it is necessary to:

- Carry out in-depth systematic research and analysis of occupational injuries, especially for FAs in the $S$ and $M$ group;

- Advocate and implement continuous professional education and worker education, training and certification of working skills;

- Draw up an action plan for proactive introduction of high technologies and more efficient and humane forestry work;

- Improve its safety record and reputation in order to attract future generations to the company/sector;

- Interconnect Croatia forestry sector in the European process and programs related to health and safety in forestry;

- Develop a culture of safety, with synergistic and joint efforts of key stakeholders in the forestry sector, and change the focus of looking at the issue of occupational safety from a point of marginal importance or cost to a point of primary importance or investment.

Examples of successful safety and health improvements arise from accident reporting and discuss various legal and regulatory approaches for improving worker safety and health. Poje and Potočnik [35] point out that a lower frequency of injuries at work can be achieved through the unconditional commitment to the safety culture at all organizational levels. The International Labor Organization (ILO) also noted that the key element of occupational health and safety management is the promotion of a culture of prevention in the enterprise [36]. Exceptional safety requires more than simply following procedures, complying with safety and health standards and wearing PPE. Instead, people must look for and report hazards, give peers feedback on safe and at-risk behaviour, volunteer for safety committees, make suggestions for improvement and, most difficult of all, admit to mistakes so lessons can be learned. When people are recognized for what they do well regarding safety, they will be more engaged and invested in achieving an exceptional safety culture $[2,37]$. Therefore, the introduction of a proactive safety culture can lead to further reduction in work injuries and diseases [19,38,39].

In addition, the safety and prevention of work-related injuries also has a significant role in the process of certification of forest management according to the FSC standard. According to the mentioned, the recent version of the German FSC International Forest Certification Standards has set clear requirements for operators working with a chainsaw and for legal entities performing wood harvesting activities in forestry. Professional workers, but also non-professionals, must prove their training in accordance with the European Chainsaw Certificate (ECC) as one of the conditions for meeting FSC principles 1 and 4 [40].

Author Contributions: Conceptualization, M.L. and I.M.; Methodology, M.L. and M.Š.; Validation, I.M., M.B. and M.Š.; Formal analysis, M.L. and D.M.; Data curation, M.L.; Writing-original draft preparation, M.L.; Writing - review and editing, M.Š. and I.M.; Visualization, M.B. and D.M. All authors have read and agreed to the published version of the manuscript.

Funding: This research was funded by the Croatian Science Foundation grant number IP-2020-027637. The APC was funded by the Croatian Science Foundation and the Faculty of Forestry and Wood Technology of Zagreb University.

Institutional Review Board Statement: The study was conducted according to the guidelines of the Declaration of Helsinki, and approved by the Ethics Committee of Faculty of Forestry and Wood Technology of Zagreb University (protocol code 251-72-06-20-1, 22 January 2020). 
Informed Consent Statement: Not applicable.

Data Availability Statement: Data supporting this study may be provided upon reasonable request to the authors of the study.

Acknowledgments: The research was funded by the Croatian Science Foundation within the Project «Increasing the Competitiveness of Forestry Sector Through Development of Safety Culture (ForSaf2024)», project number IP-2020-02-7637.

Conflicts of Interest: The authors declare no conflict of interest.

\section{References}

1. Gejdoš, M.; Vlčkova, M.; Allmanova, Z.; Blažova, Ž. Trends in Workplace Injuries in Slovak Forest Enterprises. Int. J. Environ. Res. Public Health 2019, 16, 141. [CrossRef] [PubMed]

2. Garland, J.; Cedergren, J.; Eliasson, L.; van Hensbergen, H.; McEwan, A.; Wästerlund, D. Occupational Safety and Health in Forest Harvesting and Silviculture-A Compendium for Practitioners and Instructors; Forestry Working Paper No. 14; FAO: Rome, Italy, 2020. [CrossRef]

3. EU-OSHA. Occupational Safety and Health in Europe's Forestry Industry. European Agency for Safety and Health at Work. 2008. Available online: https:/ / osha.europa.eu/en/publications/e-facts/efact29/view (accessed on 28 March 2020).

4. Adams, G.; Armstrong, H.; Cosman, M. Independent Forestry Safety Review-An Agenda for Change in the Forestry Sector. 2014; 12p, Available online: http:/ / fica.org.nz/wp-content/uploads/2014/10/IFSRReportSummary-Web.pdf (accessed on 20 July 2021).

5. Gallis, C. Work-related prevalence of musculoskeletal symptoms among Greek forest workers. Int. J. Ind. Ergon. 2006, 36, 731-736. [CrossRef]

6. Bovenzi, M. A Follow up study of vascular disorders in vibration-exposed forestry workers. Int. Arch. Occup. Environ. Health 2008, 81, 401-408. [CrossRef]

7. Fonseca, A.; Aghazadeh, F.; de Hoop, C.; Ikuma, L.; Al-Qaisi, S. Effect of noise emitted by forestry equipment on workers' hearing capacity. Int. J. Ind. Ergon. 2015, 46, 105-112. [CrossRef]

8. Blombäck, P. Improving occupational safety and health: The International Labour Organization's contribution. In Applying Reduced Impact Logging to Advance Sustainable Forest Management; Enters, T., Durst, P.B., Applegate, G.B., Kho, P.C.S., Man, G., Eds.; Asia Pacific Forestry Commission and FAO: Bangkok, Thailand, 2002; Chapter 19.

9. Poschen, P. Forestry a Safe and Healthy Profession? Unasylva 172 1993, 44, 3-12.

10. Staal, D. Heat Stress in Forestry Work. Ph.D. Thesis, Department of Silviculture, University of Agricultural Sciences, Bengaluru, India, 2001. Available online: https:/ / pub.epsilon.slu.se/16/ (accessed on 20 July 2021).

11. Garland, J.J. Accident Reporting and Analysis in Forestry: Guidance on Increasing the Safety of Forest Work; Forestry Working Paper No. 2; FAO: Rome, Italy, 2018.

12. International Labour Organization (ILO). Occupational Safety and Health in Forestry. Report II, Forestry and Wood Industries Committee, Second Session; ILO: Geneva, Switzerland, 1991.

13. Potočnik, I.; Pentek, T.; Poje, A. Severity Analysis of Accidents in Forest Oparations. Croat. J. For. Eng. 2009, 30, 171-184.

14. Suchomel, J.; Belanová, K.; Vlčková, M. Analysis of occupational accidents occurrence in Slovakian forestry. In Proceedings of the International Scientific Conference "Technology and Ergonomics in the Service of Modern Forestry", Krakow, Poland, 26-29 June 2011; pp. 93-105.

15. Landekić, M. Organizacijska kultura i sigurnost pri radu u Hrvatskom šumarskom sektoru. Šumarski List 2010, 134, 613-622.

16. Efthymiou, P. Wood Harvesting; Aristotle University of Thessaloniki: Thessaloniki, Greece, 2008.

17. Yovi, E. Assessing OSH protection on forestry work through competency approach. Indones. J. Physiol. 2009, 8, 94-100.

18. Musić, J.; Halilović, V.; Lojo, A.; Šporčić, M.; Đonlagić, A. Analysis of Safety at Work in Forestry of the Federation B\&H-Case Study. Nova Meh. Šumar. 2019, 40,31-41.

19. Kim, Y.; Park, J.; Park, M. Creating a Culture of Prevention in Occupational Safety and Health Practice. Saf. Health Work 2016, 7, 89-96. [CrossRef]

20. EHS Today (Environmental Health and Safety Today). Cornerstones to Building a Successful Safety Culture. 2016. Available online: https: / www.ehstoday.com/safety-leadership/slc-2016-cornerstones-building-successful-safety-culture (accessed on 28 March 2021).

21. Yin, R.K. Case Study Research: Design and Methods, 4th ed.; SAGE: Thousand Oaks, CA, USA, 2009.

22. Anon. Report of the Work Protection Service in Croatian Forests Ltd. for the Period 2014-2020; Hrvatske šume d.o.o.: Zagreb, Croatia, 2021; Available online: https://www.hrsume.hr/index.php/hr/godisnja-poslovna-izvjesca (accessed on 12 April 2021).

23. Anon. Forest Management Plan-Plan Proceeding. Valid from 2016 to 2025. Forest Management Area of the Republic of Croatia. Available online: https://poljoprivreda.gov.hr/UserDocsImages/dokumenti/sume/sumarstvo/sumskogospodarska_osnova201 6-025/SUMSKOGOSPODARSKA_OSNOVA_2016.pdf (accessed on 20 July 2021).

24. Landekić, M.; Šporčić, M.; Martinić, I.; Bakarić, M. Influence of organizational culture on firm efficiency: Competing values framework in Croatian forestry. Scand. J. For. Res. 2015, 30, 624-636. [CrossRef] 
25. Bojanin, S.; Krpan, A.P.B. Mogućnost tzv. visokoga i potpunog mehaniziranja sječe i izrade te mehaniziranja privlačenja drva u šumama Hrvatske (Possibilities for high level and complete mechanization in felling operations and mechanization in skidding in Croatian forests). Šumarski List 1997, 121, 371-381.

26. Mederski, P.S.; Borz, S.A.; Đuka, A.; Lazdinš, A. Challenges in Forestry and Forest Engineering-Case Studies from Four Countries in East Europe. Croat. J. For. Eng. 2021, 42, 117-134. [CrossRef]

27. Šporčić, M.; Sabo, A. Ozljeđivanje radnika u hrvatskom šumarstvu tijekom razdoblja 1991-2000. Šumarski List 2002, 126, $261-271$.

28. Grzywinski, W.; Skonieczna, J.; Jelonek, Z.; Tomczak, A. The Influence of the Privatization Process on Accident Rates in the Forestry Sector in Poland. Int. J. Environ. Res. Public Health 2020, 17, 3055. [CrossRef] [PubMed]

29. Martinić, I.; Landekić, M.; Šporčić, M.; Lovrić, M. Šumarstvo na pragu Evropske Unije-koliko smo spremni na području sigurnosti pri šumskom radu? Croat. J. For. Eng. 2011, 32, 431-441.

30. Grzywinski, W.; Sawa, L.; Nowik, A.; Nowicki, G. Structure of work accidents in the Regional Directorate of the State Forests in Szczecinek in the years 1990-2009. Sylwan 2013, 157, 403-411.

31. Varakina, Z.L.; Vyazmin, A.M.; Sannikov, A.L.; Nygard, C.H.; Grjibovski, A.M. Fatal occupational injuries in the Arkhangelsk region, Northwest Russia. Occup. Med. Oxf. 2010, 60, 470-475. [CrossRef] [PubMed]

32. Benavides, F.G.; Benach, J.; Muntaner, C.; Delclos, G.L.; Catot, N.; Amable, M. Associations between temporary employment and occupational injury: What are the mechanisms? Occup. Environ. Med. 2006, 63, 416-421. [CrossRef] [PubMed]

33. Halilović, V.; Mahmutović, Z. Zaštita na Radu u šumarstvu (Safety at Work in Forestry); Samostalni Sindikat Šumarstva, Prerade Drveta i Papira BiH: Sarajevo, Bosnia and Herzegovina, 2020; p. 197.

34. Poje, A. Nezgode pri delu v gozdarskih izvajalskih podjetjih Slovenije v letu 2002. Gozdarski Vestn. 2013, 61, 360-371.

35. Poje, A.; Potočnik, I. Forestry Ergonomics and Occupational Safety in High Ranking Scientific Journals. Croat. J. For. Eng. 2017, 38, 291-310.

36. International Labour Organization (ILO). Information on Decent Work and a Health and Safety Culture; Office: Geneva, Switzerland, 2009; Available online: http://www.ilocarib.org.tt/portal/index.php?option \protect\$relax \protect $\backslash \backslash$ begingroup1 $\backslash$ endgroup \@@over4\}\$com_content\&task \protect\$relax \protect $\{\backslash$ begingroup $1 \backslash$ endgroup $\backslash @ @ o v e r 4\} \$$ view\&id $\backslash$ protect $\$$ relax \protect $\backslash$ begingroup $1 \backslash$ endgroup $\backslash @ @ o v e r 4\} \$ 1138 \& I t e m i d \backslash p r o t e c t \$$ relax $\backslash$ protect $\{\backslash$ begingroup $1 \backslash$ endgroup $\backslash @ @ o v e r 4$ \}\$1141 (accessed on 15 April 2021).

37. Yovi, E.Y.; Yamada, Y. Addressing Occupational Ergonomics Issues in Indonesian Forestry: Laborers, Operators, or Equivalent Workers. Croat. J. For. Eng. 2019, 40, 351-363. [CrossRef]

38. Nielsen, J.K. Improving safety culture through the health and safety organization: A case study. J. Saf. Res. 2013, 48, 7-17. [CrossRef] [PubMed]

39. Borz, S.A.; Talagai, N.; Cheţa, M.; Chiriloiu, D.; Montoya, A.V.-G.; Vizuete, D.D.C.; Marcu, M.V. Physical Strain, Exposure to Noise and Postural Assessment in Motor-Manual Felling of Willow Short Rotation Coppice: Results of a Preliminary Study. Croat. J. For. Eng. 2019, 40, 377-388. [CrossRef]

40. German FSC Standard. German FSC Standard 3-0, Version 17.04.2018. Available online: https://www.fsc-deutschland.de/dede/wald/revision-des-deutschen-fsc-standards/erlaeuterungen-waldstandard-3-0 (accessed on 6 March 2021). 